\title{
Towards Achieving MDGS in Africa: The Role of the Institute of Forensic Accountants (IFA) Nigeria in Eradicating Corruption
}

\author{
Faboyede, Olusola Samuel ${ }^{1}$, Mukoro, Oluku Dick ${ }^{2}$, Ben-Caleb, Egbide ${ }^{3}$ \\ ${ }^{I}$ Department of Accounting, College of Development Studies, Covenant University, Canaanland, Ota, Ogun \\ State, Nigeria. \\ ${ }^{2}$ Department of Accounting, College of Development Studies, Covenant University, Canaanland, Ota, Ogun \\ State, Nigeria. \\ ${ }^{3}$ Department of Accounting, College of Development Studies, Covenant University, Canaanland, Ota, Ogun \\ State, Nigeria.
}

\begin{abstract}
African countries have adopted the Millennium Development Goals (MDGs) as a tool within their wider development planning framework, in order to improve the living conditions of their citizens. MDGs are measurable targets attached to a timeframe for making a difference in the lives of the people. This paper, against the background that corruption poses the greatest threat to the commitment of Governments to provide resources and policies to implement the MDG goals, looks at the invaluable role played by the Institute of Forensic Accountants, Nigeria, in wiping out the evils of corruption and bad governance. Forensic accounting is the intersection between accounting, investigations, and law. The paper asserts that the war against corruption will not be fruitful without the concerted integration of forensic accountants into the governance framework. It strongly advocates a highly sincere will of the Nigerian government to support the widespread growth of forensic accounting in its bid to wage the anti-graft war, restore deprived basic human rights, such as health, education, shelter and security as well as tackle the challenges of poverty and infrastructural/economic development.
\end{abstract}

Keywords: Corruption, Forensic Accountants, Governance, IFA, MDGs.

\section{Introduction}

Millennium Development Goals (MDGs) address a set of key issues that detail how Africa can fight extreme poverty, hunger and disease by year 2015. It has been said that many African countries are not yet on track to meet these goals even though appreciable strides have been made in some countries, especially in the areas of increasing school enrolment, improving access to clean water and expanding HIV/AIDS treatment (Elsheikh, 2008). African countries have a chance of meeting the poverty reduction target possibly by 2015 or beyond provided they enjoy the right mix of policies. But this feat is hinged on fundamental imperatives such as transparency/accountability, improved governance, and foreign aid/investment flow. In times past, African countries have generally found it difficult to keep up with their promises of embracing good governance and corruption free systems which are critical ingredients to attracting vital foreign capital funds.

The concern for the development of instruments which allow monitoring embedded in a nationally owned process accounts for the reason why there is so much interest, among both African and donor countries, in the African Peer Review Mechanism (APRM) which is a process in which African countries assess each other's performance against measures of good governance. The essence is to improve African policy-making through policy assessment and sharing of experiences. The APRM is underlined by the basic idea of countries being assessed via two routes, which are both based on agreed values, codes and standards laid down in a questionnaire covering the areas of democracy, political governance, economic governance, corporate governance, management, and socio-economic development. By inference therefore, the APRM is a critical ingredient in achieving the MDGs. According to Economic Commission for Africa (2005a), developing countries participating in the APRM need to improve their general governance performance by spelling out specific policy measures in the programme of action towards realizing the MDGs.

The policies and capacity to deliver the MDGs will not stand if corruption and bad governance thrive in the society as there will, for instance be an impediment to the factor of adequate external financing which counts so much in achieving the envisaged progress in these nations by the due date of 2015. For instance, many have defended the donor community's delay in providing the pledged 0.7 percent of gross national incomes to help kick start African economies and extricate countries from gross poverty by arguing that aid has been pumped into African economies over the years to no avail or that inefficient African governments should be blamed for the misery in Africa. 
This paper enunciates the threats corruption and bad governance pose to the realization of the MDG goals in Africa. It posits that the way out of the menace of these twin evils is a political commitment to the advancement of forensic accounting. This is being engendered through the pioneering efforts of the Institute of Forensic Accounting (IFA) Nigeria. The paper submits that priotising the growth of forensic accounting will result in success stories underlined by sustainable growth, efficient use of domestic and external resources, human development, deepening macroeconomic reforms, enhanced domestic competitiveness and efficiency, as well as strengthened democratic institutions and financial management systems. Thus, African countries still lagging behind in achieving the MDGs will be able to make significant strides or accelerated progress as a result of better policies and improved capacity to make good use of available resources. These options are the keys to achieving the MDGs (Economic Commission for Africa, 2005b). The paper has four sections comprising introduction, relevant literature review, methodology, as well as findings, recommendations, and conclusion.

\section{Achieving the MDGs in Africa}

In Africa, there are critical living challenges such as poverty, hunger, joblessness, diseases, lack of shelter, environmental deterioration and gender inequality. It was the need to address these challenges that prompted African leaders into adopting the MDGs. The MDGs are tools that can advance as well as fast-track the national development agendas of African countries. The MDG goals centre on: (1) eradicating extreme poverty and hunger (2) achieving universal primary education (3) promoting gender equality (4) reducing child mortality (5) reducing maternal mortality (6) combating HIV/AIDS, malaria, and other diseases, and (7) ensuring environmental sustainability. Between 1990 and 2002, Africa's progress towards achieving the MDGs fared worst while that of the rest of the world was a significant one. Africa not only experienced the slowest overall progress but suffered reversals in crucial areas like living standards and adult life expectancy. While North Africa has made substantial progress in actualizing most of the MDG goals, progress in South South African countries remains unsatisfactory although a few countries like Botswana and Mauritius have made some concrete progress (Fosu, 2005).

Despite advances in some of the African countries, the majority of them may be unable to realize the MDGs by 2015, given the current status quo. Implementing the eight MDGs requires the approval of rational and well-placed policies that encourage broad economic growth. Since Africa is an area of particular poverty, there must be vigorous intervention underlined by good governance and anti-corruption strategies. In Africa, the imperatives of easing the achievement of the MDGs include: maintenance of peace and social harmony, attraction of private sector investment, reformed legal and judicial framework, war against corruption, reformed financial sector, and investment in education cum health sectors (Roy, 2005).

\subsection{The Corruption and Governance Challenges}

According to Harsch (2005), Africa will need an additional $\$ 25$ bn in aid by 2010 to enable it make essential investments that will improve economic growth and the lives of its poorest people. For the aid to be effectively utilized, African countries must strengthen democracy, combat corruption and enhance performance.

Africa has been lagging behind in achieving the MDGs due to a range of factors which include: weak economic growth, accountability, the rule of law, corruption, and business environment unfriendly to domestic and foreign investors. These have resulted in weak capacity to carry out basic functions of government as well as the provision of public goods.

Although the credibility of the G8 countries is at risk because they are dangerously behind on their landmark commitments to Africa, having delivered only $\$ 3$ billion of the promised $\$ 25$ billion in additional assistance by 2010, they have nonetheless made a strong call for greater accountability and compliance with anti-corruption measures on the part of the African region (Hubbard, 2008). Simmons (2007a) notes that corruption is harmful to every government and losing resources to corrupt leaders particularly devastating, especially in poor nations where every single dollar lost translates to one less child in school or one less well dug in clean water provision. Only honest governments stand the chance of attracting direct assistance through private relief and development agencies. A Wall Street Journal editorial asserts that one of the best places to start the fight to reduce global poverty is fighting corruption (Simmons 2007b).

Corruption has multiplier adverse effects on economic growth - it deters investment, hinders good governance, culminates in wastes and distorts allocation of resources, undermines credibility of public authority as well as increases political insecurity. The combined effect of corruption and poverty has the potential to depress economic growth and increase inequality.

The World Bank Institute (WBI) in conjunction with the Canadian Parliamentary Centre is interested in fostering innovative ways and mechanisms to enhance the capacity for effective performance, oversight of public policy, and development in an effort to address the challenges posed by endemic poverty, corruption and unimpressive economic performance (Parliamentary Centre, 2006). 
The Millennium Declaration recognizes governance as a critical element for achieving the Millennium Development Goals. The Millennium Declaration represents the most forceful and explicit commitment by the UN member states to date to the principles of good governance. It makes explicit reference to good governance in two paragraphs stating that "democratic and participatory governance best assures the rights to live in dignity, free from hunger and from fear of violence, oppression or injustice (para.1.6)" and that "success in meeting the objectives of development and the elimination of poverty depends on good governance" (para. III. 13). Governance is therefore regarded today as an essential prerequisite for human development. The concept of governance has actually evolved from its original focus on economic process and administrative efficiency to one with stronger links to democracy, the rule of law and participation (United Nations University, 2008).

Corruption hampers economic growth, prevents countries from capitalizing on internal resources, reduces aid effectiveness, and contributes significantly to hunger and malnutrition. It implies schools are never built or that education systems remain drastically under capacity. Corruption further means hospitals are poorly staffed/resourced, circulation of fake/potentially lethal drugs facilitated and poor health system. It makes environmental regulations remain unenforceable, resulting in lost livelihood, illness and social displacement for majority. It also engenders greater business risks, stifles cross-border trade, distorts markets and discourages foreign direct investment (Transparency International, 2005).

\subsection{About Forensic Accounting}

Forensic accounting is the unique practice area of accounting that is concerned with engagements which result from actual or anticipated disputes or litigation. It is one of the newer areas as well as the fastest growing area of accounting. The word "Forensic" means "suitable for use in a court of law", and it constitutes the guiding benchmark of the work of forensic accountants. Forensic accountants usually do give expert evidence at the eventual trial. Their job involves the integration of accounting, auditing, and investigative skills.

They are trained to look beyond the numbers while dealing with the reality of business contexts. Forensic accountants are hired by business organizations and the government to investigate, analyze, interpret, summarize, and present complex financial and business information in an understandable and properly supported manner. They engage two principal tools namely investigative accounting and litigation support. They also assist with the recovery of assets by way of civil or criminal prosecution and obtaining documentation to form an initial assessment of a case as well as identifying areas of loss.

Investigations may border on criminal issues, bankruptcy, shareholders and partnership disputes, personal injury claims, business interruptions, property losses, employee fidelity claims, fraud, matrimonial disputes, business economic losses (e.g. contract disputes, construction claims, expropriations, product liability, trademark or patent infringements, and losses occurring from a breach of agreement), professional negligence, as well as mediation and arbitration. Others include: accounting malpractice, determination of compliance, insurance casualty claims, loss measurement, economic harm analysis/economic loss analysis, claims analysis, abuses of trust relationships, general commercial litigation, royalty audits, expert witness testimony, and discovery assistance.

A number of accounting firms have forensic accounting departments where sub-specializing forensic accountants may be found (Institute of Forensic Accountants, Nigeria (IFA), n.d.).

\subsection{The Institute of Forensic Accountants (IFA) Nigera.}

The Institute of Forensic Accountants (IFA) Nigeria was incorporated under Limited by Guarantee by the Corporate Affairs Commission (CAC), Abuja after receiving the written consents of the Federal Ministry of Education, Abuja, the attorney General, and Minister of Justice of the Federation, Abuja. IFA was also backed up by decree No 1 of 1990 as a professional institution for the provision of bonafide qualifications for Forensic Accountants via the administration of Professional Examinations. Its purpose was to provide qualified forensic accountants who will inspire public confidence in litigation matters relating to detection of fraud and abuse which include the likes of white-collar crimes and economic losses. It is a platform for the advancement of the anti-fraud professionals who are interested in obtaining high quality continuing professional education on forensic accounting. IFA gives specialized training and skills that are not typically part of an accountant's formal education due to the reason that forensic accounting plays a unique role in the society. 1FA educational programmes allow its members to earn credentials that can help assure the legal community, employers, individuals, and other stakeholders that they (members) possess exceptional degree of experience and knowledge required to provide competent professional forensic accounting services.

According to IFA, Nigeria (n.d.), the institute's mission includes: promotion and development of the science of forensic accountancy which blends education with experience; promoting the application of accounting, auditing and investigative skills to uncover truth and form legal opinions; providing qualified members who will assist in both litigation support (calculation and estimation) and estimation of economic damages and related issues; the advancement of education, particularly industrial and commercial education 
through the involvement of the study of the skills of forensic accountancy for the benefit of the community and the industrial, trade/commerce sectors.

Further, the institute is empowered: to foster and maintain investigations and research into the best means and methods of applying high standards of forensic accountancy in industry, trade and commerce; to encourage, extend, increase, disseminate and promote knowledge and the exchange of information and ideas in regard to forensic accountancy; to be appointed to carry out an investigation and audit of organizations; to hold, carry on or arrange and conduct meetings, conferences, schools and visit, whether local, national or international, for those engaged in forensic accountancy in industry, trade and commerce; to prepare and make available to members, publications dealing with the objectives and functions of the Institute; to establish and maintain a Library available to the members in order to aid in study of forensic accountancy in industry, trade and commerce; to prescribe, uphold and improve the standards of training, experience and skills of persons engaged in forensic accountancy; to promote schemes of examinations and admissions for those seeking qualifications as forensic accountants; to establish such things as may advance and promote the advancement of the profession of forensic accountancy in Nigeria and the International arena; and to form branches in any part of the world for the promotion of all or any of the above mentioned objectives.

\subsection{Nature of Work of IFA Members}

The nature of IFA members' work include: (a) performing an orderly analysis, investigation, inquiry, test, inspection, or examination to obtain the truth and form an expert opinion (b) giving evidence in Federal and State courts (c) developing complex financial models, which identify key drivers in business and facilitate planning and forecasting (d) assisting lawyers in litigation cases (e) giving expert counsels in business investigation and valuation for litigation and forensic accounting purposes (f) helping in alternative dispute resolution, arbitrations, economic loss claims, loss of profit claims, professional negligence, and fraud investigation $(\mathrm{g})$ performing forensic accounting and litigation support services, including the provision of written and oral evidence in law courts (h) acting as expert witness as well as consulting experts, in addition to preparation of expert reports and or giving of oral testimonies in tribunals and courts (i) undertaking other forensic accounting activities, which include a wide range of fraud risk management engagements (i) playing helpful roles to help management of organizations, internal auditors and or external auditors to better understand the true nature and extent of fraud and related risk and how to manage those risks (j) giving advice on capital rising to clients $(\mathrm{k})$ conducting due diligence enquiries, preparations of public reports and expert evidence (l) helping in matters that are subject to complex arbitration procedures $(\mathrm{m})$ helping in investigations into collapse of organizations, and (n) rendering services as well as assisting companies involved in capital rising and floats. Indeed, the aforementioned are just a few of the jobs of forensic accountants as they are too numerous.

\section{Methodology}

The methodological approach adopted for this research paper is that of the secondary data. A secondary data is that which has been collected by others for purposes other than those of a particular research study. This includes information from sources such as journals, textbooks, the internet (information super-highway), etc. In employing this methodology, particular attention was paid to elements such as definitions used, measurement error, source bias, reliability and data time span. The major rationale behind this is that the use of relevant secondary data obviates the need for primary research to be undertaken at all in this context, the reason being the theoretical/conceptual nature of the paper which combines beautifully with the empirical case study of the IFA, Nigeria. This has enabled the assemblage and analysis of more accurate information which is needed to sensitize Africa to the imperatives of fighting corruption/ bad governance through forensic accounting in the journey to realizing the MDGs (Agriculture and Consumer Protection, n.d.).

\section{Findings, Recommendations and Conclusion}

The MDGs are an international commitment to human development. They provide Africa with new impetus to reverse deterioration and embody several national and international development initiatives.

Corruption cum poor governance is key obstacle to development as it undermines material well being and social justice. It entrenches poverty and hunger, deprives children of primary education, results in fatalities from treatable illness, child mortality, and childbirth death, while it also leads to unsustainable development and impeded economic growth. Forensic accountants are professionals trained to nip the corruption scourge in the bud and the campaign for transparency and accountability in governance in Africa will not be fruitful without a rugged commitment to the promotion of forensic accounting. This vanguard is being championed by the IFA, Nigeria through its vision, mission and activities.

Africa still has a chance to get back on track to achieve the MDGs through a conceptual framework which is being evolved by the emergence of the IFA in Nigeria. Governments must adopt this conceptual framework which, amongst other things, encourages: equitable distribution of income, second generation of 
poverty reduction strategies (e.g. improvement of governance capacity and deeper ownership through meaningful stakeholder consultation), investment in human capital via high levels of education , mitigating 'brain drain' through better governance and economic policies, and creating a general enabling environment.

The enabling environment context must encompass: peace and security, quality institutions, infrastructure and support for private sector, removal of regulatory burdens, provision of legal protection of private property, and enforcement of laws in an equitable manner. Finally, corruption is a massive drag on efforts to reach the MDGs. Thus, MDGs are unreachable without unflinching commitment to fighting corruption through forensic accounting in Nigeria and Africa.

\section{References}

[1]. El-sheikh, Consensus for Achieving the MDGs in Africa. 2008. http://content.undp.org/go/newsroom/2008/July/consensus-forachieving-the-mdgs- in-africa.en;sessionid

[2]. Economic Commission for Africa, Better Governance, More Goals Achieved. 2005a. http://www.uneca.org/mdgs/story2september05.asp

[3]. Economic Commission for Africa, MDGs - It's not the money but what you do with it. 2005b http://www.uneca.org/mdgs/story1 september05.asp

[4]. A. Fosu, Achieving the Millennium Development Goals (MDGs) in Africa: An Issues Paper. A presentation at Conference of African Ministers of Finance,

[5]. Planning and Economic Development, 11-13 May, 2005, Abuja. http://www.uneca.org/conferenceofministers/2005/documents/cm

[6]. J. Roy, Implementing the Millennium Development Goals: Our Human

[7]. Rights Obligation. Conference Report, Ottawa, 8-9 June, 2005. http://www.dd-rd.ca/site/publications/index

[8]. E. Harsch, Focusing Aid on Africa's Own Priorities. Africa Renewal, Vol 19 No 2

[9]. 2005, pg 10. http://www.un.org/ecosocdev/geninfo/afrec/vol19no2/192_pg15 htm

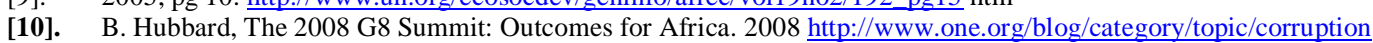

[11]. V. Simmons, McCain: Countries Should be Accountable for HIV Spending. 2007a. http://www.one.org/blog/category/topic/corruption.

[12]. V. Simmons, Fighting Corruption. 2007b http://www.one.org/blog/category/topic/corruption.

[13]. Parliamentary Centre, Corruption, Poverty and Growth: Progress, Prospects and Challenges in Africa and Asia. Africa-Asia Policy Dialogue. Dar es Salaam, Tanzania. September 25-27, 2006. http://www.parlcent.ca/africa/docs

[14]. United Nations University, The Governance Dimension of the MDGs in Africa. 2008. http://543789.gridserver.com/eventsforums/africa/2008/the-governance-dimension- of-th.html

[15]. Transparency International, Millennium Development Goals are unreachable without Commitment to Fighting Corruption. 2005. http://www.transparency.org

[16]. Institute of Forensic Accountants, Nigeria (n.d.) Guide To Membership and Examination Syllabus. http://www.ifa-ng.org

[17]. Agriculture and Consumer Protection, Marketing Research and Information Systems. FAO Corporate Document Repository, n,d,. http://www.fao.org/docrep 